\title{
PERKEMBANGAN OOSIT INDUK Osteochilus hasselti C.V. YANG DIBERI HORMON ESTRADIOL-17 $\beta$ DAN PAKAN DENGAN KADAR PROTEIN BERBEDA
}

\author{
Andri Prajaka Santo, Untung Susilo, Gratiana E Wijayanti
}

Fakultas Biologi, Universitas Jenderal Soedirman, Jalan dr. Suparno 63 Purwokerto 53122

\section{A B S T R A C T}

The availability of fish seed is very important in fish propagation. Good quality of fish seeds were produced by a good brooder which characterized a large number of egg production at spawning. The aims of this research were to evaluate the oocytes development in the hard-lipped Barb (Osteochilus hasselti C.V.) given 17ß-estradiol, different percentage of protein in the diet, and their combination. This research was conducted experimentally applying Factorial Completely Randomized Design. The first factor was percentage of protein in the diet consisted of 4 levels namely $25 \%\left(\mathrm{P}_{1}\right), 30 \%\left(\mathrm{P}_{2}\right), 35 \%\left(\mathrm{P}_{3}\right)$, and $40 \%\left(\mathrm{P}_{4}\right)$, the second factor was dose of $17 \beta$-estradiol benzoate (EB) consisted of 3 levels namely $0 \mu \mathrm{g} / \mathrm{kg}$ of body weight $\left(D_{0}\right), 126 \mu \mathrm{g} / \mathrm{kg}$ of body weight $\left(D_{1}\right)$, and $210 \mu \mathrm{g} / \mathrm{kg}$ of body weight $\left(D_{2}\right)$, thus there were 12 combinations of treatment with 3 replicates. The results showed that neither of protein proportion or $17 \beta$-estradiol affected the proportion of oocytes of any developmental stage $(p>0,05)$ within the first two weeks post spawning. The treatments, however, significantly increased the proportion of oocytes at V3-V5, V6-V7, and post-vitellogenic stages $(\mathrm{p}<0,05)$ started at week $4^{\text {th }}$ post spawning. The GSI increased in correlation to the proportions of oocytes at stage $\geq V 6(r=0,701 ; p<0,01)$ and the dose of $17 \beta$-estradiol ( $r=$ $0.357, \mathrm{p}<0.05$ ). There was no significant different on GSI amongst the experimental groups. The HSI tend to decrease as the dose of $17 \beta-$ estradiol increased $(r=-0.210, p>0.05)$. In conclusion, the percentage of protein in the diet and different doses of $17 \beta$-estradiol improved oocyte development of Hard-Lipped Barb (Osteochilus hasselti C.V.).

KEY WoRDS: Osteochilus hasselti, $17 \beta$-estradiol, protein content of diet, oocyte diameter, oocyte proportion

Penulis korespondensi: GRATIANA E WIJAYANTI | email: bugrat_1@yahoo.co.uk

\section{PENDAHULUAN}

Keberadaan benih penting dalam usaha budidaya perikanan. Benih yang baik harus dihasilkan dari induk yang baik pula. Induk ikan yang baik memiliki gonad yang mampu menghasilkan telur dalam jumlah optimum. Maka dari itu, salah satu usaha yang dilakukan untuk mendapatkan induk dengan gonad yang baik adalah dengan pemberian pakan berprotein tinggi dan pemberian hormon untuk membantu memacu perkembangan gonad ikan.

Kualitas telur sangat ditentukan oleh kualitas dan kuantitas kandungan nutrien dalam pakan. Pakan yang diberikan pada ikan ada dua macam, yaitu pakan dengan protein dominan dari sumber hewani dan pakan dengan protein dominan dari sumber nabati. Batubara (2009), menjelaskan bahwa kuantitas dan kualitas pakan, yakni protein, lemak dan vitamin yang diberikan kepada induk merupakan faktor penting yang memiliki hubungan erat dengan kematangan gonad, jumlah telur yang diproduksi, dan kualitas telur serta larva. Halver dan Hardy (2002), menjelaskan bahwa intake protein atau asam amino sangat dibutuhkan oleh ikan karena digunakan secara langsung untuk pertumbuhan dan reproduksi serta mengganti jaringan yang rusak.

Kebutuhan protein pada ikan beragam menurut sifat pemakan dari ikan tersebut. Ikan Mas (Cyprinus carpio) dan Blue Tilapia (Oreochromis aureus) masingmasing membutuhkan protein sebesar 38\% dan 34\% (Halver dan Hardy, 2002), sedangkan pada ikan Nila (Oreochromis niloticus) yaitu 35\% (Jauncey dan Ross, (1982) dalam Batubara, (2009)). Menurut Gunasekera et al. (1996) dalam Gunadi et al. (2010), ikan nila yang diberi pakan dengan kadar protein 20\% dan 35\% menghasilkan telur lebih banyak dalam setiap pemijahan dibandingkan dengan ikan nila yang diberi pakan dengan kadar protein $10 \%$. Hasil penelitian Djajasewaka et al. (2005) dalam Samsudin et al. (2010), menunjukkan bahwa untuk pertumbuhan dan perkembangan gonad ikan nilem membutuhkan protein pakan dengan kadar $27-42 \%$.

Faktor internal dalam induk yang juga sangat mempengaruhi perkembangan gonad adalah hormon. Salah satu hormon yang berperan penting dalam perkembangan gonad ikan adalah estradiol $\left(E_{2}\right)$. Pada hewan ovipar termasuk ikan, $\mathrm{E}_{2}$ mengontrol proses vitellogenesis pada hepar (Melamed dan Sherwood, 2005). Tingginya $E_{2}$ dalam plasma dapat mempercepat proses pematangan gonad. Dosis $E_{2}$ sebesar 200-600 $\mu \mathrm{g} / \mathrm{kg}$ berat badan induk dapat meningkatkan kadar $\mathrm{E}_{2}$ dalam plasma ikan baung (Hemibagrus nemurus Blkr.) (Utiah, 2008). Keterlibatan $\mathrm{E}_{2}$ dalam vitelogenesis telah diteliti pada berbagai jenis ikan, antara lain ikan mas (Cyprinus carpio) (Galas et al., 1999), jambal siam (Pangasius hypophthalmus) (Indriastuti, 2000), Heteropneustes fossilis (Singh et al., 2007), Kutum (Rutilus frisii kutum) (Heidari et al., 2010), ikan tilapia Oreochromis mossambicus (Cornish, 1998), dan ikan lele dumbo (Clarias gariepinus) (Phartyal et al., 2005).

Penelitian ini dilakukan dengan tujuan untuk mengetahui:

1. Perkembangan oosit ikan nilem yang diberi hormon estradiol-17 $\beta$ dengan dosis berbeda.

2. Perkembangan oosit ikan nilem yang diberi pakan dengan kadar protein berbeda. 
3. Perkembangan oosit ikan nilem yang diberi kombinasi antara estradiol-17 $\beta$ dan pakan dengan kadar protein berbeda.

\section{MET O DE}

Bahan-bahan yang digunakan dalam penelitian ini adalah induk betina ikan nilem ( $O$. hasselti C.V.) pasca mijah sebanyak 72 ekor; hormon estradiol benzoat (17ß-Estradiol benzoate, Batch No. 20090512, ARGENT Laboratories, Inc., Makati City, Philippines); GnRH analog (Syndel, Vancouver, Cannada); larutan $\mathrm{NaCl}$ 0,9\%; alkohol 70\%; larutan fiksatif Normal Buffered Formalin (NBF); methyllen blue, kemikalia untuk pengukuran kualitas air (DO dan COD); dan bahanbahan untuk pembuatan pelet pakan ikan meliputi tepung ikan, tepung ampas tahu, tepung kecambah kedelai, tepung tapioka, vitamin kompleks dan air.

Alat-alat yang digunakan meliputi alat untuk pemijahan dan pemeliharaan, peralatan untuk pengukuran kualitas air, alat untuk pembuatan pelet, alat pembuatan dan penyuntikkan hormon estradiol, dan alat pengambilan dan evaluasi perkembangan oosit. Alat untuk pemijahan dan pemeliharaan induk ikan nilem meliputi 18 buah akuarium berkapasitas $90 \mathrm{l}$ sebanyak beserta perlengkapan aerasinya, spuit injeksi volume $1 \mathrm{ml}$, dan kain basah, selang untuk penyiponan sepanjang $1 \mathrm{~m}$.

Peralatan untuk pengukuran sifat fisik-kimia kualitas air meliputi kertas $\mathrm{pH}$ indikator dan thermometer dan botol Winkler untuk mengambil air saat pengukuran COD dan DO. Alat untuk pembuatan pelet meliputi timbangan, kompor, dandang, alat penggiling pelet, baki, dan oven. Alat untuk pembuatan larutan stok dan penyuntikan hormon estradiol$17 \beta$ meliputi vortex, tabung sentrifugasi mikro $1,5 \mathrm{ml}$, mikropipet $200 \mu \mathrm{l}$, dan spuit injeksi $1 \mathrm{ml}$. Alat pengambilan sampel oosit meliputi kanula (Terumo Feeding Tube, FT 0880 Fr. 8, panjang $40 \mathrm{~cm}$ ), spuit injeksi ukuran $3 \mathrm{ml}$, timbangan analitik dengan ketelitian 0,01 g,botol sampel, dan pipet transfer. Alat untuk evaluasi perkembangan oosit meliputi mikroskop cahaya, gelas objek, eye piece micrometer.

Penelitian ini dilaksanakan di Laboratorium Struktur dan Perkembangan Hewan, Fakultas Biologi, Universitas Jenderal Soedirman. Penelitian ini dilakukan selama sepuluh bulan yaitu bulan Juli 2012 - Maret 2013.

Penelitian dilakukan secara eksperimental dengan menggunakan rancangan dasar yaitu, rancangan acak lengkap (RAL) pola faktorial $4 \times 3$. Faktor pertama persentase protein dalam pakan terdiri atas 4 taraf yaitu 25\% $\left(\mathrm{P}_{1}\right), 30 \%\left(\mathrm{P}_{2}\right), 35 \%\left(\mathrm{P}_{3}\right)$, dan $40 \%\left(\mathrm{P}_{4}\right)$, faktor kedua adalah hormon estradiol-17 $\beta$ benzoat (EB) berdasarkan dosis yang sudah ditetapkan yaitu $0 \mu \mathrm{g} / \mathrm{kg}$ berat badan $\left(\mathrm{D}_{0}\right)$, $126 \mu \mathrm{g} / \mathrm{kg}$ berat badan $\left(D_{1}\right)$, dan $210 \mu \mathrm{g} / \mathrm{kg}$ berat badan $\left(D_{2}\right)$, dengan demikian terdapat 12 kombinasi perlakuan masing-masing dengan 3 ulangan.

Parameter yang diamati dalam penelitian ini terdiri dari parameter utama dan parameter pendukung. Parameter utama dalam penelitian ini yaitu perkembangan oosit meliputi diameter oosit, proporsi oosit, morfologi oosit, jumlah oosit yang diperoleh, dan jumlah oosit tahap $\geq$ V6 . Parameter pendukung penelitian ini adalah Indeks Gonadosomatik (IGS) dan Indeks Hepato-somatik (IHS).

Tabel 1. Kombinasi Perlakuan antara Kadar Protein dalam Pakan dengan Dosis Estradiol

\begin{tabular}{clcccc}
\hline & & \multicolumn{2}{c}{ Pakan (P) } \\
\cline { 3 - 5 } & & $\mathrm{P}_{1}(25 \%)$ & $\mathrm{P}_{2}(30 \%)$ & $\mathrm{P}_{3}(35 \%)$ & $\mathrm{P}_{4}(40 \%)$ \\
\hline \multirow{3}{*}{ Dosis E } & & $\left.\mathrm{P}_{2}(\mathrm{D}) \mu \mathrm{g} / \mathrm{kg} \mathrm{BB}\right)$ & $\mathrm{P}_{1} \mathrm{D}_{0} \mathrm{D}_{0}$ & $\mathrm{P}_{3} \mathrm{D}_{0}$ & $\mathrm{P}_{4} \mathrm{D}_{0}$ \\
& $\mathrm{D}_{1}(126 \mu \mathrm{g} / \mathrm{kg} \mathrm{BB})$ & $\mathrm{P}_{1} \mathrm{D}_{1}$ & $\mathrm{P}_{2} \mathrm{D}_{1}$ & $\mathrm{P}_{3} \mathrm{D}_{1}$ & $\mathrm{P}_{4} \mathrm{D}_{1}$ \\
& $\mathrm{D}_{2}(210 \mu \mathrm{g} / \mathrm{kg} \mathrm{BB})$ & $\mathrm{P}_{1} \mathrm{D}_{2}$ & $\mathrm{P}_{2} \mathrm{D}_{2}$ & $\mathrm{P}_{3} \mathrm{D}_{2}$ & $\mathrm{P}_{4} \mathrm{D}_{2}$ \\
\hline
\end{tabular}

Keterangan: $\mathrm{P}=$ Persentase Protein dalam Pakan $\left(\mathrm{P}_{1}=25 \% ; \mathrm{P}_{2}=30 \% ; \mathrm{P}_{3}=35 \% ; \mathrm{P}_{4}=40 \%\right), \mathrm{D}=$ Dosis Estradiol-17 $\beta$ yang diberikan $\left(\mathrm{D}_{0}=0 \mu \mathrm{g} / \mathrm{kg}\right.$ BB; $\left.D_{1}=126 \mu \mathrm{g} / \mathrm{kg} \mathrm{BB} ; \mathrm{D}_{2}=210 \mu \mathrm{g} / \mathrm{kg} \mathrm{BB}\right)$

Akuarium yang digunakan dalam penelitian ini adalah akuarium plastik yang memiliki volume $90 \mathrm{l}$. Jumlah akuarium yang digunakan adalah 12 buah. Setiap akuarium diisi ikan nilem pasca mijah masing-masing sejumlah 6 pasang. Sebelum digunakan akuarium dicuci, kemudian diberikan methyllene blue sebagai pencegahan penyakit agar selama penelitian nanti diharapkan ikan tetap hidup dan sehat.

Sumber protein hewani yang digunakan dalam pembuatan pelet ikan ini adalah tepung ikan dikombinasikan menggunakan bahan-bahan lain seperti tepung kedelai, ampas tahu, dan bekatul. Kadar protein dalam pakan yang ditargetkan adalah 25\%, 30\%, 35\% dan $40 \%$. Sebagai perekat digunakan tepung tapioka dengan komposisi $10 \%$ dari total jumlah pelet yang akan dibuat. Campuran komponen pakan dicetak menjadi pelet menggunakan alat penggiling daging, kemudian dikeringkan di dalam oven pada temperatur $70^{\circ} \mathrm{C}$ selama 2 hari. Kandungan protein dalam pelet yang dihasilkan dianalisis proksimat di Laboratorium Ilmu Nutrisi dan Makanan Ternak Fakultas Peternakan Unsoed untuk memastikan kandungan protein sesuai dengan formulasi bahan yang dibuat.

Hormon estradiol-17 $\beta$ yang digunakan dalam bentuk serbuk. Sebelum disuntikkan, dibuat stock sesuai dosis yang akan disuntikkan yaitu $126 \mu \mathrm{g} / \mathrm{kg}$ berat badan dan 210 $\mu \mathrm{g} / \mathrm{kg}$ berat badan ikan. Larutan stock dibuat dengan melarutkan $1 \mathrm{mg}$ estradiol benzoat dengan $1 \mathrm{ml}$ minyak zaitun. Estradiol yang telah dilarutkan dalam minyak zaitun kemudian dihomogenkan menggunakan vortex.

Persiapan yang dilakukan meliputi seleksi induk ikan nilem betina matang gonad. Ikan yang digunakan dalam penelitian ini merupakan induk pasca mijah. Induk pasca mijah diperoleh dengan menginduksi induk-induk betina dan jantan matang gonad menggunakan $0,5 \mathrm{~mL} / \mathrm{kg}$ berat badan GnRH analog. Induk betina yang telah diinduksi dipasangkan dengan induk jantan, setiap akuarium diisi dengan satu induk betina dan satu induk jantan. Keberhasilan pemijahan ditandai dengan terdapatnya sel telur dalam jumlah banyak di dasar akuarium dan warna air yang keruh oleh warna milt. Induk yang telah memijah ditempatkan pada akuarium pemeliharaan dengan kepadatan 6 induk ikan betina dengan 6 induk ikan jantan dalam satu akuarium

Satu minggu pasca pemijahan, induk dipelihara dalam akuarium dan diberi pakan sesuai dengan persentase protein yang sudah ditentukan selama 8 minggu. Pakan diberikan satu kali sehari sebanyak 3\% dari bobot tubuh ikan. Estradiol-17 $\beta$ diberikan sekali yaitu pada minggu pertama pasca mijah. Sedangkan untuk kontrol $(0 \mu \mathrm{g} / \mathrm{kg}$ berat badan) hanya diinduksi dengan minyak zaitun.

Pengambilan data dilakukan setiap dua minggu sekali mulai minggu II, IV, VI, dan VIII melalui kanulasi. Pada minggu VIII oosit diambil untuk menghitung jumlah oosit 
tahapan $\geq$ V6. Oosit yang diperoleh dimasukkan ke dalam botol sampel yang telah diisi dengan larutan fiksatif NBF. Sampel oosit diamati dan dihitung menggunakan mikroskop cahaya. Diameter oosit diukur menggunakan eye piece micrometer yang telah telah dikalibrasi. Proporsi oosit pada masing-masing tahapan perkembangan dihitung dengan menggunakan rumus:

$$
\text { Proporsi Tahapan } \mathrm{x}=\frac{\sum \text { oosit tahap } \mathrm{x}}{\sum \text { oosit sampel total }} \times 100 \%
$$

Selain itu, dilakukan juga perhitungan jumlah oosit tahapan $\geq V 6$, dengan menggunakan rumus:

$$
\Sigma \text { Oosit tahap } \geq \text { V6 }=\frac{\text { berat gonad }}{\Sigma \text { Oosit tahapan } \geq \mathrm{V} 6} \times 100 \%
$$

Pada minggu VIII, ikan dari semua kelompok perlakuan dibedah, diambil gonad dan heparnya guna perhitungan Indeks Gonado-somatik (IGS) dan Indeks Hepato-somatik (IHS). Menurut Effendie (2002) dalam Tuapetel (2009), perhitungan IHS, dan IGS dilakukan dengan metode Gravimetrik. Indeks Gonado-somatik (IGS) dihitung menggunakan rumus:

$$
\mathrm{IGS}=\frac{\mathrm{Wg}}{\mathrm{Wt}} \times 100 \%
$$

Keterangan :

$\mathrm{W}_{\mathrm{g}}=$ Berat Gonad $(\mathrm{g})$

$\mathrm{W}_{\mathrm{t}}=$ Berat Tubuh $(\mathrm{g})$

Indeks Hepato-somatik (IHS) dihitung menggunakan rumus:

$$
\mathrm{IHS}=\frac{\mathrm{Wh}}{\mathrm{Wi}} \times 100 \%
$$

Keterangan:

$\mathrm{W}_{\mathrm{h}}=$ Berat hati ikan $(\mathrm{g})$

$\mathrm{W}_{\mathrm{i}}=$ Berat ikan uji $(\mathrm{g})$

Kualitas fisika-kimia air yang diukur meliputi $\mathrm{pH}$, temperatur, COD, dan DO. Pengukuran COD menggunakan metode SNI 06-6989.15:2004, Sedangkan DO menggunakan metode SNI 06-6989.14:2004. Pengukuran keempat parameter tersebut dilakukan dua kali selama periode penelitian.

Data proporsi oosit, IGS, IHS, dan jumlah oosit tahap $\geq$ V6 dianalisis dengan menggunakan uji Anova dua arah dengan signifikansi 5\% $(\alpha=0,05)$ (Steel dan Torrie, 1993). Hasil uji Anova yang signifikan dilanjutkan dengan uji BNJ. Data dalam bentuk persentase ditransformasi terlebih dahulu ke dalam bentuk Arcsir/x sebelum dianalisis. Keterkaitan antara nilai proporsi oosit, IGS, IHS, dan jumlah oosit $\geq$ V6 dengan persentase protein dalam pakan dan dosis estradiol$17 \beta$ yang diberikan dianalisis menggunakan uji korelasi.

\section{HASIL DAN PEMBAHASAN}

Proporsi oosit berbagai tahapan pada minggu ke-2 pasca mijah atau minggu pertama pasca induksi estradiol-17 $\beta$ tampak pada Gambar 1.a. Proporsi oosit tahap V3-V5 pada minggu kedua pasca mijah berkisar antara $40,49 \pm 17,91 \%$ pada P4D1 hingga $91,67 \pm 40,07 \%$ pada P2D1; tahap V6-V7 berkisar antara $6,25 \pm 10,83 \%$ pada P2D1 hingga $34,42 \pm 25,00 \%$ pada P4D1; dan tahap post-vitelogenik berkisar antara 2,08 $\pm 3,61 \%$ pada P2D1 hingga $42,76 \pm 3,90 \%$ pada P1D0. Hasil uji Anova menunjukkan bahwa pemberian estradiol-17 $\beta$ tidak memberikan hasil yang berbeda nyata terhadap semua tahapan oosit
( $p>0,05)$. Sementara itu, hasil uji Anova menunjukkan kombinasi pemberian pakan berprotein dan estradiol$17 \beta$ juga tidak meningkatkan proporsi oosit tahap V3V5, V6-V7 dan post-vitelogenik ( $>>0,05)$. Hasil uji Anova menunjukkan bahwa persentase protein dalam pakan yang diberikan meningkatkan proporsi oosit tahap V6-V7 $(\mathrm{p}<0,05)$, selanjutnya hasil uji BNJ menunjukkan bahwa pemberian pakan dengan protein $40 \%$ meningkatkan proporsi oosit tahap V6V7.

Dinamika perkembangan oosit ikan nilem di minggu ke-4 disajikan pada Gambar 1.b. Proprosi

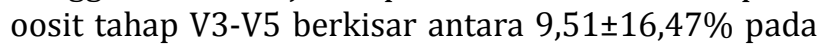
P1D0 hingga $97,71 \pm 32,69 \%$ pada P2D2. Proporsi oosit tahap V6-V7 berkisar antara 1,19 $\pm 1,35 \%$ pada P2D2 hingga $24,12 \pm 8,76 \%$ pada P1D2. Sedangkan Proporsi oosit tahap post-vitelogenik berkisar antara $1,10 \pm 0,97 \%$ pada P2D2 hingga $50,07 \pm 46,66 \%$ pada P4D0. Hasil uji Anova menunjukkan bahwa persentase protein dalam pakan yang diberikan meningkatkan proporsi oosit tahap V3-V5 dan V6-V7 $(\mathrm{p}<0,01)$. Pemberian estradiol-17 $\beta$ meningkatkan proporsi oosit tahap V3-V5 dan V6-V7 $(\mathrm{p}<0,05)$. Hasil signifikan dilanjutkan dengan uji BNJ yang menunjukkan bahwa pakan dengan kandungan protein 30\% yang dikombinasikan dengan estradiol$17 \beta$ dosis $126 \mu \mathrm{g} / \mathrm{kg}$ BB meningkatkan proporsi oosit tahap V3-V5, sedangkan pakan dengan kandungan protein 35\% yang dikombinasikan dengan estradiol$17 \beta$ dosis $210 \mu \mathrm{g} / \mathrm{kg}$ BB meningkatkan proporsi oosit tahap V6-V7. Sementara itu, persentase protein dalam pakan dan estradiol-17 $\beta$ yang diberikan tidak meningkatkan proporsi oosit tahap post-vitelogenik $(\mathrm{p}>0,05)$.

Dinamika perkembangan oosit diamati kembali di minggu ke-6 pasca mijah (Gambar 1.c.) Proporsi oosit tahap V3-V5 di minggu ini berkisar antara $27,84 \pm 23,93 \%$ pada P4D1 hingga $86,60 \pm 36,05 \%$ pada P4D0. Proporsi oosit tahap V6-V7 berkisar antara $5,78 \pm 9,44 \%$ pada P2D0 hingga $32,72 \pm 13,18 \%$ pada P4D1. Proporsi oosit tahap post-vitelogenik berkisar antara $4,35 \pm 1,82 \%$ pada P2D1 hingga $56,22 \pm 47,04 \%$ pada P3D0. Hasil uji Anova menunjukkan bahwa persentase protein dalam pakan yang diberikan dapat meningkatkan proporsi oosit tahap V3-V5 $(\mathrm{p}<0,05)$, dan pemberian estradiol-17 $\beta$ dapat meningkatkan proporsi oosit tahap V6-V7 $(\mathrm{p}<0,01)$. Hasil uji BNJ menunjukkan pakan dengan kandungan protein $30 \%$ meningkatkan proporsi oosit tahap V3-V5, sedangkan estradiol- $17 \beta$ baik dosis $126 \mu \mathrm{g} / \mathrm{kg}$ BB maupun 210 $\mu \mathrm{g} / \mathrm{kg}$ BB berpengaruh meningkatkan proporsi oosit tahap V6-V7. Pakan dengan kadar protein dan dosis estradiol-17 $\beta$ yang berbeda tidak dapat meningkatkan proporsi oosit tahap post-vitelogenik.

Dinamika perkembangan oosit ikan nilem pada minggu ke-8 tampak pada Gambar 1.d.). Proporsi oosit tahap V3-V5 di minggu ini berkisar antara $26,01 \pm 10,1 \%$ pada P4D1 hingga $77,64 \pm 28,94 \%$ pada P1D2. Proporsi oosit tahap V6-V7 berkisar antara $3,11 \pm 3,24 \%$ pada P2D0 hingga $48,36 \pm 36,70 \%$ pada 
P3D1. Proporsi oosit tahap post-vitelogenik berkisar antara 17,02 $\pm 29,48 \%$ pada P3D1 hingga $69,79 \pm 10,79 \%$ pada P4D1. Hasil uji Anova menunjukkan persentase protein dalam pakan $(\mathrm{p}<0,05)$ dan estradiol-17 $\beta(\mathrm{p}<0,01)$ meningkatkan proporsi oosit tahap V6-V7. Hasil uji BNJ menunjukkan bahwa pakan dengan kandungan protein 35\% yang dikombinasikan dengan estradiol$17 \beta$ dosis $126 \mu \mathrm{g} / \mathrm{kg}$ BB meningkatkan proporsi oosit tahap V6-V7, sedangkan pemberian pakan dengan persentase protein berbeda dan estradiol-17 $\beta$ tidak meningkatkan proporsi oosit tahap V3-V5 dan postvitelogenik $(p>0,05)$.

Pemberian pakan berprotein dan estradiol-17 $\beta$ terhadap perkembangan oosit ikan nilem di minggu ke-2 pasca memijah belum menunjukkan adanya peningkatan yang berarti. Pemberian pakan berprotein tampak tidak meningkatkan proporsi oosit tahap V3-V5 dan post-vitelogenik. Proporsi oosit tahap V6-V7 menunjukkan peningkatan pada ikan yang diberipakan dengan protein $40 \%$. Pemberian estradiol-17 $\beta$ tidak meningkatkan proporsi oosit pada berbagai tahapan.

Dalam penelitian ini kadar estradiol-17 $\beta$ tidak diukur disetiap minggunya sehingga tidak diketahui secara pasti dinamika kadar estradiol-17 $\beta$ pada ikan nilem setiap minggunya. Akan tetapi, kadar estradiol$17 \beta$ pada ikan nilem sudah dilakukan dalam penelitian Rahayuningsih (2012), yang diamati pada minggu pertama hingga minggu ke tiga pasca mijah. Hasil penelitian Rahayuningsih (2012), menunjukkan bahwa pada minggu pertama pasca induksi estradiol$17 \beta$ dengan dosis yang sama diberikan pada perlakuan ini, kadar estradiol-17 $\beta$ di dalam plasma darah ikan nilem pascamijah belum meningkat secara signifikan. Hal ini dimungkinkan karena ovarium ikan nilem masih berada pada fase recovery pasca pemijahan. Fase ini ditandai dengan masih tingginya kadar progesteron (Asturiano et al., 2002; Hoar et al., 1983). Kadar progesteron ikan nilem saat minggu ke2 pasca mijah berisar antara 0,22-0,51 ng/ml lebih tinggi bila dibandingkan minggu pertama pasca mijah yaitu 0,22 ng/ml (Fannessia, 2011). Masa recovery pasca pemijahan pada ikan dapat berbeda-beda menurut spesiesnya. Menurut Zadmajid et al. (2012), kadar estradiol-17 $\beta$ ikan gold fish (Carassius auratus) menurun drastis pasca ovulasi dan mencapai level terendah pada hari kelima pasca ovulasi, kemudian kadarnya di dalam plasma meningkat kembali secara perlahan saat memasuki vitelogenesis baru. Hal ini menyebabkan peran estradiol-17 $\beta$ dalam menstimulasi hepar untuk mendeposisikan protein yolk (Vtg) ke dalam oosit berlangsung dengan frekuensi yang sangat rendah pada awal vitellogenesis (Campbell, 1978 dalam Luquet dan Watanabe, 1986).

Peran protein dalam pakan dan estradiol-17 $\beta$ dalam perkembangan oosit ikan nilem tampak pada minggu ke-4 periode pemeliharaan. Pada minggu ini secara umum proporsi oosit tahap V3-V5 dan postvitelogenik mengalami peningkatan, namun tidak pada proporsi oosit tahap V6-V7. Hasil penelitian Fannessia (2011), menunjukkan proporsi oosit ikan nilem tahap V3-V5 dan post-vitelogenik meningkat secara perlahan di minggu ke-3 dan minggu ke-4 pascamijah. Hal ini dimungkinkan karena adanya perkembangan oosit ke tahapan selanjutnya, yaitu dari tahapan yang lebih muda ke tahapan yang lebih matang. Peran pakan dan estradiol- $17 \beta$ penting pada minggu ini. Peningkatan tahapan vitelogenik berakibat pada meningkatnya kebutuhan asam amino dan estradiol-17 $\beta$ (Babin et al., 2007).

Pada minggu ke-6 pemeliharaan, secara umum rerata proporsi oosit tahap V3-V5 lebih rendah dibandingkan pada minggu ke-4 pasca pemijahan. Rerata proporsi oosit dari semua perlakuan menunjukkan peningkatan jumlah oosit tahap V6-V7 dari minggu ke-4 ke minggu ke-6. Hal ini dimungkinkan karena adanya perekrutan tahapan V3V5 ke tahapan V6-V7 sehingga menyebabkan penurunan proporsi oosit tahap V3-V5 pada periode tersebut. Hasil penelitian Fannessia (2011), menunjukkan bahwa proporsi oosit ikan nilem tahap V3-V5 cenderung mengalami penurunan di minggu ke-6 pascamijah, sedangkan proporsi oosit tahap V6V7 mengalami peningkatan di minggu yang sama. Sementara itu, tahapan post-vitelogenik meningkat dari minggu ke-2 hingga minggu ke-6 pemeliharaan. Pakan dengan kandungan protein $30 \%$ baik tanpa pemberian estradiol-17 $\beta$ maupun dengan kombinasi estradiol-17 $\beta$ berpengaruh signifikan terhadap peningkatan proporsi oosit tahap V3-V5. Pemberian estradiol-17 $\beta$ dosis $126 \mu \mathrm{g} / \mathrm{kg}$ BB maupun $210 \mu \mathrm{g} / \mathrm{kg}$ BB dapat meningkatkan proporsi oosit tahap V6-V7 di minggu ini.

Pengaruh persentase protein dalam pakandan estradiol-17ßterhadap proporsi oosit tahap V6-V7 mulai tampak sejak minggu ke-4 pascamijah. Hal ini sejalan dengan pernyataan Babin et al. (2007), bahwa peran asam amino dan estradiol-17 $\beta$ meningkat selama tahap vitelogenesis akhir sampai menuju maturasi oosit. Akan tetapi, peningkatan proporsi oosit tahap V6-V7 tidak menyebabkan peningkatan terhadap proporsi oosit tahap post-vitelogenik.

Pada minggu ke-8 pemeliharaan, dinamika perkembangan oosit yang terjadi menunjukkan adanya penurunan rerata proporsi oosit tahap V3-V5 dari seluruh perlakuan yang diujikan. Proporsi oosit tahap V6-V7 sedikit mengalami penurunan dibandingkan minggu sebelumnya, kecuali padapemberian pakan dengan kandungan protein $35 \%$ yang dikombinasikan dengan estradiol-17 $\beta$ dosis $126 \mu \mathrm{g} / \mathrm{kg} \mathrm{BB}$, proporsi oosit tahapan V6-V7 mengalami peningkatan. Pada minggu ini proporsi oosit tahap post-vitelogenik cenderung meningkat meskipun tidak signifikan. Peningkatan proporsi oosit tahap post-vitelogenik diduga karena adanya perekrutan oosit tahap V6-V7 ke tahap berikutnya. Tahapan post-vitelogenik merupakan tahapan akhir dari perkembangan oosit sebelum memasuki maturasi (Nagahama, 1994). Hasil serupa dijumpai pada ikan 
gold fish (Carassius auratus) (Zadmajid et al., 2012) dan ikan trout (Hoar et al., 1983), kadar estradiol-17 $\beta$ menurun pada tahapan post-vitelogenik sampai menjelang ovulasi. Pada tahapan tersebut peran estradiol-17 $\beta$ menurun dan digantikan oleh peran MIH (Maturation Inducing Hormone) yaitu progesteron $(17,20 \beta \mathrm{P}$ atau DHP) yang distimulasi oleh LH. Menurut Babin et al. (2007), LH menstimulasi sel granulosa pada oosit guna memproduksi $\mathrm{MIH}$ selama tahapan akhir vitellogenesis sampai penyelesaian GVBD. Oosit tahapan post-vitelogenik (PV) dapat tertahan sampai beberapa bulan sampai adanya stimulasi lingkungan, sosial, atau isyarat feromon sehingga memulai kembali proses maturasi akhir yang membuka kembali proses meiosis yang sempat tertahan (Yaron dan Levavi-Sivan, 2011).

Berdasarkan dinamika perkembangan oosit ikan nilem yang dipelihara selama 8 minggu, secara umum dapat dijelaskan bahwa: (1), Bila pakan yang diberikan memiliki kandungan protein yang rendah (25-30\%), pemberian estradiol-17 $\beta$ dapat meningkatkan proporsi oosit tahap V3-V5; (2), Bila pakan yang diberikan memiliki kandungan protein yang tinggi ( $>30 \%$ ), pemberian estradiol-17 $\beta$ dapat menekan proporsi oosit tahap V3-V5.

Selama vitellogenesis, ikan membutuhan protein sebagai bahan baku dalam proses sintesis protein yolk (vitellogenin) dan choriogenin lebih tinggi dari biasanya (Arukwe dan Goksøyr, 2003; Reidel et al., 2010). Peningkatan kadar protein dalam pakan berkorelasi positif dengan peningkatan proporsi oosit tahap V6-V7 di minggu ke-2 ( $\mathrm{r}=0,532 ; \mathrm{p}<0,01)$. Secara umum kebutuhan pakan dengan kandungan protein di atas 30\% dibutuhkan untuk meningkatkan proporsi oosit tahap tersebut. Pakan dengan kandungan protein $35-40 \%$ baik untuk perkembangan gonad ikan karena dapat meningkatkan diameter telur dan berat kering yang tinggi, meskipun kandungan protein 35\% menunjukkan hasil yang optimum (Abidin et al., 2006; Trushenski et al., 2006).

Hasil pengamatan histologis ovarium ikan nilem dalam penelitian Wijayanti et al. (2005), memperlihatkan bahwa pada tahapan vitelogenik-6 (V6) dan vitelogenik-7 (V7) berlangsung peningkatan deposisi globula dan granula yolk sehingga ukuran diameter oosit menjadi dua kali lebih besar bila dibandingkan tahapan vitelogenik-5 (V5). Dalam sintesis globula dan granula yolk diperlukan asam amino dan asam lemak sebagai bahan baku dan hormon estradiol-17 $\beta$ sebagai pengatur dalam proses sintesisnya. Dengan demikian, selama proses tersebut dibutuhkan asam amino dan hormon estradiol-17 $\beta$ dalam jumlah cukup.

Keterkaitan antara ketersediaan asam amino dalam protein pakan dengan keberhasilan vitellogenesis juga dijumpai pada ikan lain. Pada ikan nila (Oreochromis niloticus), kandungan protein dalam pakan sebesar 32-40\% menunjukkan perkembangan ke arah maturasi yang lebih cepat dibandingkan dengan kandungan protein kurang dari 25\% (Gunasekera et al., 1995).

Pada ikan yang sama, menurut Pangkey (2011), kandungan protein sebesar $45 \%$ menunjukkan perkembangan gonad yang lebih cepat, akan tetapi fekunditas tertinggi ditemukan pada ikan yang diberikan pakan dengan protein sebesar 25-35\%. Sedangkan pada ikan mas (Cyprinus carpio), pemberian pakan dengan kandungan protein 35\% merupakan jumlah optimum yang dibutuhkan untuk pertumbuhan dan perkembangan gonad. Hal itu tampak pada peningkatan diameter dan fekunditasnya (Roberts, 2010; Manissery et al., 2001).

Uji korelasi menunjukkan bahwa peningkatan dosis estradiol-17 $\beta$ meningkatkan proporsi oosit tahap V6-V7 baik di minggu ke-4 ( $\mathrm{r}=0,343$; $\mathrm{p}<0,05)$ maupun di minggu ke-6 ( $\mathrm{r}=0,395 ; \mathrm{p}<0,05)$. Hal ini sesuai dengan hasil penelitian Heidari et al. (2010), bahwa peran estradiol-17 $\beta$ pada perkembangan oosit Caspian kutum (Rutilus frisii) meningkat selama vitelogenesis dan mencapai puncaknya pada akhir vitelogenesis sebelum akhirnya menurun tajam selama maturasi. Estradiol-17 $\beta$ berperan dalam peningkatan deposisi globula dan granula yolk ke dalam oosit, melalui stimulasi pada sel hepar untuk mensintesis Vtg (Hoar et al., 1983). Kadar estradiol$17 \beta$ di dalam plasma darah ikan nilem diduga mengalami peningkatan di minggu ke-4 dan ke-6 masa pemeliharaan, meskipun rerata proporsi oosit tahap V6-V7 mengalami penurunan pada minggu ke-4, sedangkan proporsi oosit tahap post-vitelogenik di minggu yang sama mengalami peningkatan. Hal itu dimungkinkan karena pada saat kadar estradiol-17 $\beta$ meningkat di dalam darah, perkembangan oosit tahap V6-V7 yang sudah mencapai ukuran maksimal berkembang ke tahap post-vitelogenik, sehingga proporsi oosit tahap V6-V7 cenderung menurun pada minggu tersebut. Keberadaan estradiol-17 $\beta$ yang cukup di dalam plasma darah akan meningkatkan perkembangan oosit selama vitelogenesis menuju maturasi (Nagahama, 1994).

Hasil penelitian pada tilapia Oreochromis aureus (Cornish, 1998), ikan rainbow trout (Onchorynchus mykiss) (Nakamura et al., 2009), dan sidat Anguilla japonica (Wang dan Lou, 2007) menunjukkan bahwa selama vitellogenesis peningkatan level estradiol-17 $\beta$ dalam plasma meningkatkan perkembangan vitelogenik oosit. Jumlah oosit tahæ/6 yang diperoleh setelah 8 minggu pemeliharaan berkisar antara $372,18 \pm 324,29$ butir pada PID0 hingga $868,80 \pm 285,61$ butir pada P2D2 (Gambar 2). Hasil uji Anova menunjukkan bahwa pemberian pakan dengan persentase protein berbeda tidak meningkatkan jumlah oosit takd/6 $(p>0,05) \quad ;$ sedangkan pemberian estradiol-17 $\beta$ meningkatkan jumlah oosit tahap $\geq V 6(\mathrm{p}<0,05)$. Hasil uji BNJ menunjukkan bahwa dosis estradiol-17 $210 \mu \mathrm{g} / \mathrm{kg}$ BB terbukti dapat meningkatkan jumlah oosit tahap $\geq \mathrm{V} 6$. 

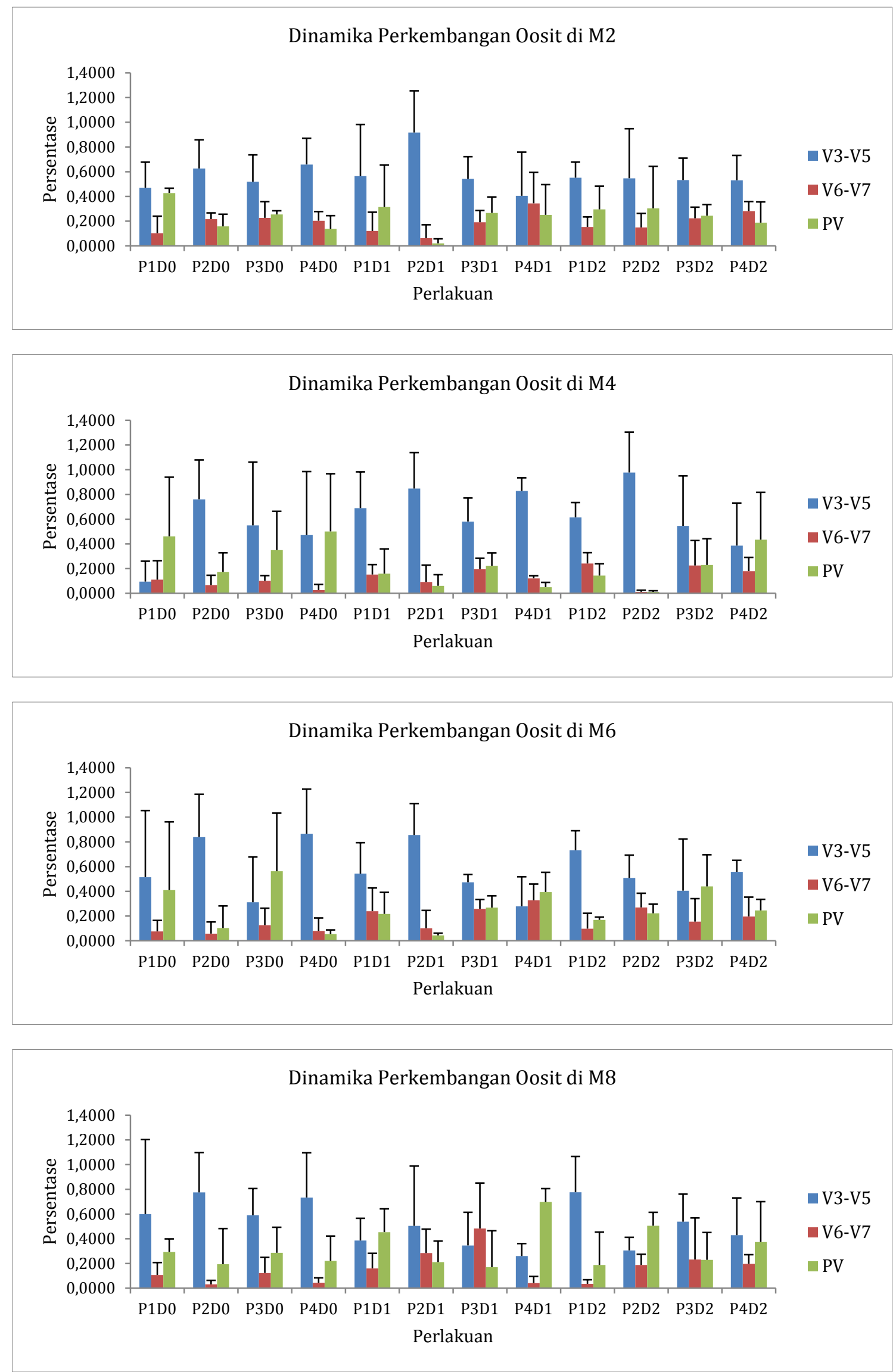

Gambar 1. Dinamika Perkembangan Oosit Induk O. hasselti C.V. di Minggu ke-2 (a), ke-4 (b), ke-6 (c), dan ke-8 (d) Pemeliharaan yang Diberi Pakan Berprotein dan Estradiol-17 $\beta$ 
Jumlah oosit tahap $\geq$ V6 terdiri dari tahapan V6, V7 dan post-vitelogenik yang berada pada midvitelogenesis hingga post-vitelogenesis (Korta et al., 2010). Uji korelasi menunjukkan bahwa peningkatan nilai IGS disebabkan karena peningkatan jumlah oosit tahap $\geq$ V6 $(\mathrm{r}=0,701 ; \mathrm{p}<0,01)$. Hal ini sejalan dengan pernyataan deVlaming et al. (1982), bahwa semakin banyak jumlah oosit tahap mid-vitelogenik dan post vitelogenik akan menentukan seberapa besar IGS yang dihasilkan. Jumlah oosit tahap $\geq$ V6 memberikan gambaran seberapa besar jumlah oosit pada tahapan tersebut yang siap untuk diinduksi menuju maturasi. Peningkatan dosis estradiol-17 $\beta$ menyebabkan peningkatan jumlah oosit tahæp V6 (r=0,496; $\mathrm{p}<0,01$ ), namun pemberian pakan berprotein tidak meningkatkan jumlah oosit tahap V6 ( $\mathrm{r}=0,160$; $\mathrm{p}>0,05)$. Hal ini sejalan dengan pernyataan Mehdinejad et al. (2013), bahwa pemberian estradiol$17 \beta$ meningkatkan tahapan vitelogenik oosit, sehingga keberadaan estradiol-17 $\beta$ memacu perkembangan tahapan vitelogenik menuju post-vitelogenik oosit pada ikan mas (Cyprinus carpio).

Secara umum, jumlah oosit tahap V6 perlu dihitung untuk mengetahui seberapa besar performa reproduksi ikan yang diberi pakan berprotein dan estradiol-17 $\beta$ terhadap oosit tahapan tersebut yang dihasilkan. Oosit tahap V6 memiliki ukuran diameter $\geq 300 \mu \mathrm{m}$ (Wijayanti et al., 2005). Oosit tahap ini memiliki tingkat penyerapan globula dan granula yolk yang tinggi, sehingga kebutuhan asam amino dan estradiol-17 $\beta$ meningkat selama tahapan ini. Semakin banyak proporsi oosit tahap vitelogenik akhir yang dihasilkan akan menentukan jumlah oosit yang dioviposisikan (Tyler et al., 1990).

Nilai IGS pada minggu ke-8 pemeliharaan berkisar $2,0 \pm 0,7 \%$ pada P4D1 hingga $7,0 \pm 2,0 \%$ pada $\mathrm{P} 2 \mathrm{D} 2$ (Gambar 3). Pakan dengan persentase protein maupun dosis estradiol-17ßyang diberikan tidak meningkatkan nilai IGS ikan nilem $(p>0,05)$. Hasil penelitian ini tidak berbeda dengan hasil penelitian Rahayuningsih (2012), yang menunjukkan bahwa nilai IGS ikan nilem yang diberikan estradiol-17 $\beta$ dengan dosis serupa dalam penelitian ini tidak mengalami peningkatan.

Hasil serupa juga terjadi pada beberapa ikan seperti ikan rainbow trout (Nakamura et al., 2009) dan ikan balashark (Balantiocheilus melanopterus Bleeker) (Zairin et al., 1996). Pemberian pakan berprotein dalam penelitian ini tidak meningkatkan nilai IGS ikan nilem. Hasil tersebut berbeda dengan hasil penelitian pada ikan baung (Mystus nemurus C.V.) yang menunjukkan bahwa pemberian pakan berprotein meningkatkan nilai IGS ikan tersebut (Muflikhah et al., 2005).

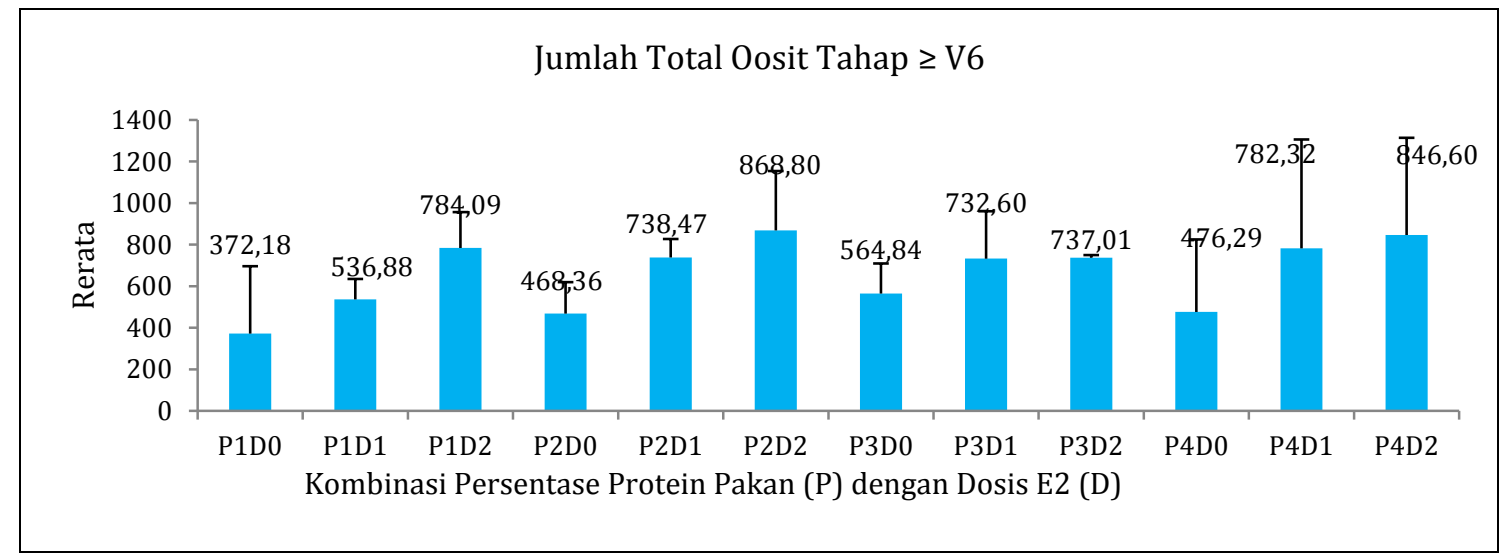

Gambar 2. Jumlah Oosit tahapan $\geq$ V6 (V6-PV) pada Ovarium Induk O. hasselti yang Diberi Pakan Berprotein dan Estradiol-17 $\beta$

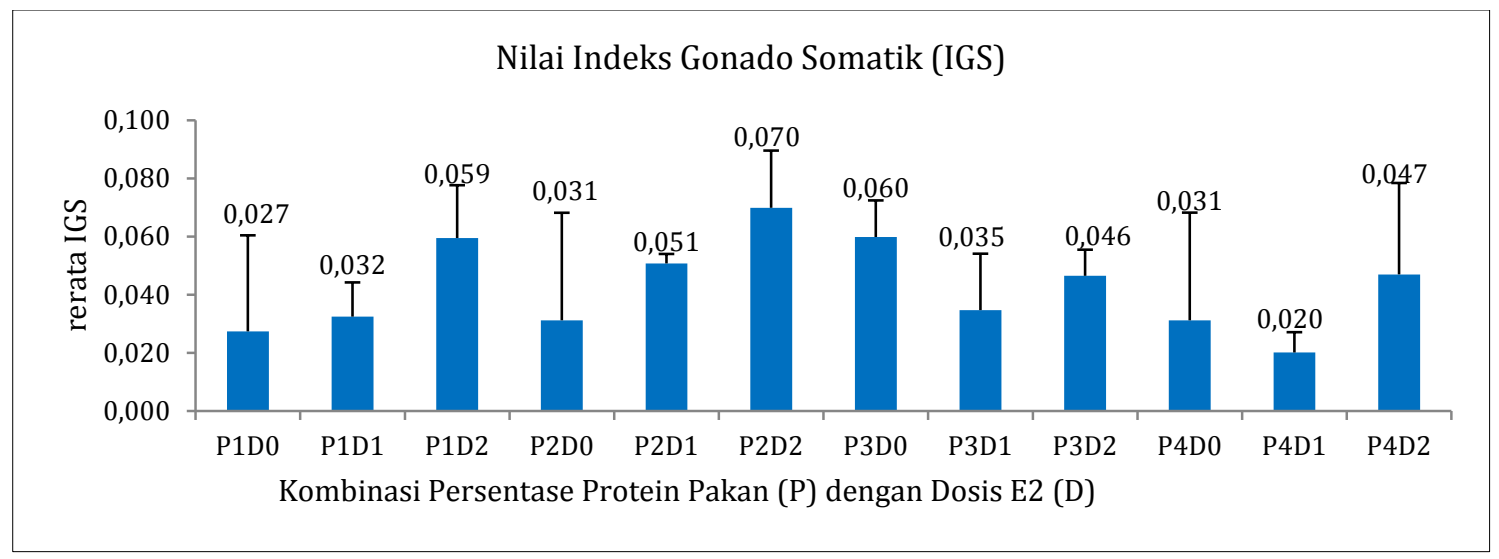

Gambar 3. Nilai IGS Induk O. hasselti Pasca Pemberian Perlakuan Berupa Persentase Protein dalam Pakan (P) dan Dosis E2 (D) Selama 8 Minggu 
Peningkatan nilai IGS pada ikan nilem berkorelasi positif dengan peningkatan dosis estradiol-17 $\beta$ yang diberikan $(\mathrm{r}=0,357 ; \mathrm{p}<0,05)$. Hasil penelitian ini sejalan dengan hasil penelitian Estay et al. (2012), yang menunjukkan bahwa peningkatan kadarestradiol-17 $\beta$ berkorelasi positif dengan peningkatan nilai IGS pada ikan rainbow trout (Oncorhynchus mykiss). Stimulasi estradiol-17 $\beta$ dalam sintesis Vtg di dalam hepar meningkatkan deposisi globula yolk dan lipid pada setiap tahapan vitelogenik sehingga menyebabkan nilai IGS meningkat (Rovara et al., 2008; Cabrita et al., 2009).

Nilai IGS ikan nilem dalam penelitian ini lebih kecil bila dibandingkan dengan hasil penelitian terhadap nilai IGS ikan nilem sebelumnya. Hal tersebut diduga disebabkan oleh beberapa faktor salah satunya adalah pola pemeliharaan. Ikan yang dipelihara di akuarium cenderung memiliki perkembangan gonad yang lebih lambat dibandingkan yang dipelihara di kolam meskipun kondisi kualitas air sama-sama dalam kisaran yang baik untuk mendukung reproduksi ikan nilem. Hasil penelitian Prayogo et al. (2008), menunjukkan bahwa nilai IGS ikan nilem betina pascamijah yang dipelihara dalam akuarium selama 8 minggu sebesar $7,3 \pm 0,8 \%$ dan pada penelitian Fannessia (2011), ikan nilem betina pascamijah yang dipelihara di akuarium selama 6 minggu memiliki nilai IGS 10,44 $\pm 7,47 \%$. Sementara itu, ikan yang dipelihara di kolam dengan periode pemeliharaan 6 minggu nilai GSI mencapai $>16 \%$ (Soeminto et al., 1995).

Nilai Indeks Hepato Somatik (IHS) induk ikan nilem setelah 8 minggu pemeliharaan berkisar antara $0,6 \pm 0,4 \%$ pada P1D1 hingga $2,4 \pm 2,1 \%$ pada P1D0 (Gambar 4). Hasil uji Anova menunjukkan bahwa persentase protein pakan dan dosis estradiol-17 $\beta$ yang diberikan tidak meningkatkan nilai IHS ikan nilem $(p>0,05)$. Hasil ini sesuai dengan hasil penelitian Rahayuningsih (2012), yang menunjukkan bahwa pemberian estradiol-17 $\beta$ tidak meningkatkan nilai IHS ikan nilem. Pemberian pakan berprotein juga tidak menunjukkan peningkatan terhadap nilai IHS pada ikan nila (Tyas, 2009).

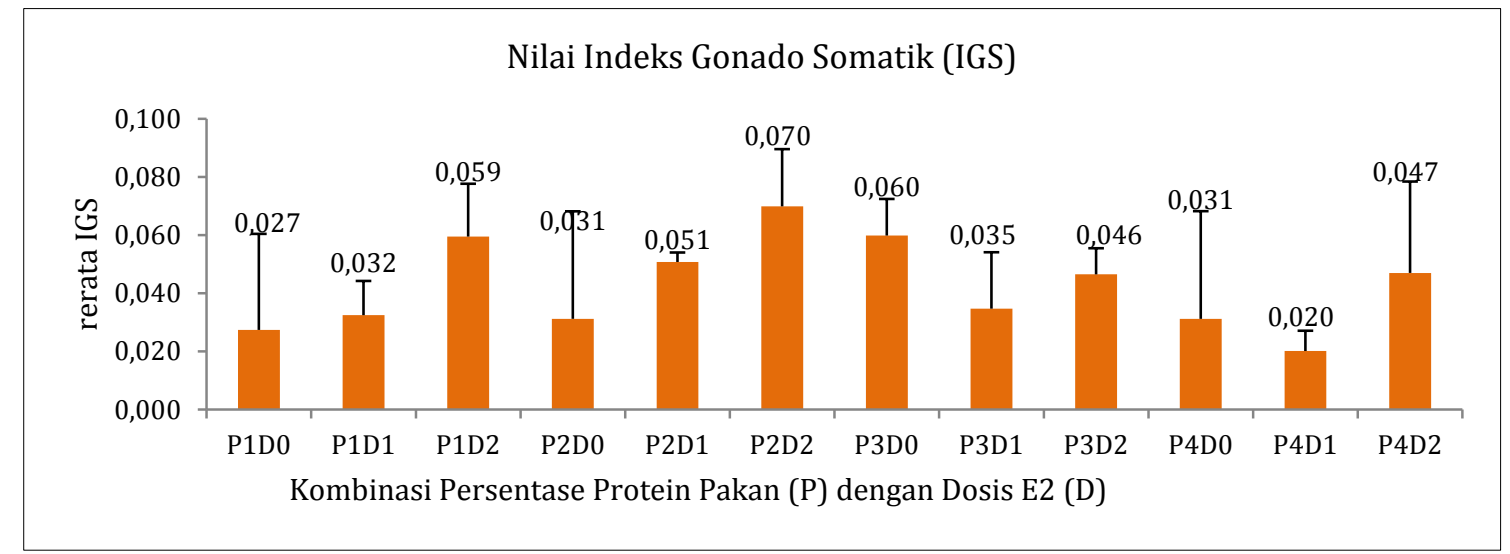

Gambar 3. Nilai IGS Induk O. hasselti Pasca Pemberian Perlakuan Berupa Persentase Protein dalam Pakan (P) dan Dosis E2 (D) Selama 8 Minggu

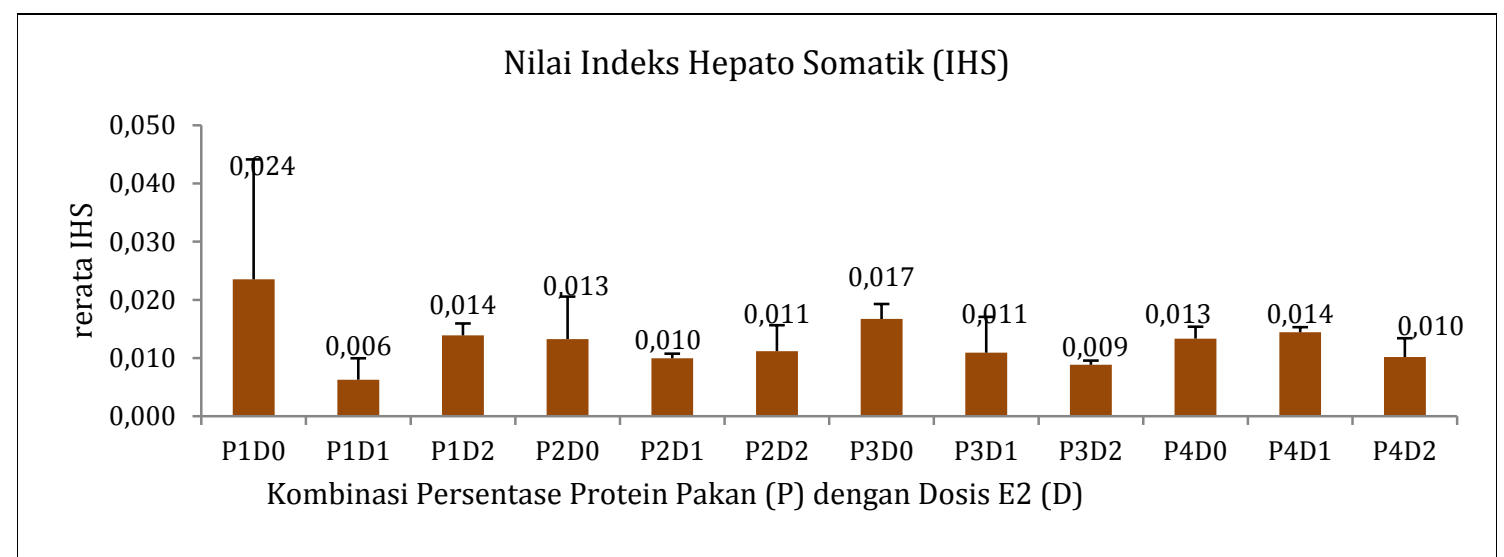

Gambar 4. Nilai IHS Induk O. hasselti Pasca Pemberian Perlakuan Berupa Persentase Protein dalam Pakan (P) dan Dosis E2 (D) Selama 8 Minggu

Nilai IHS pada induk ikan nilem setelah 8 minggu pemeliharaan tidak berbeda secara nyata pada tiaptiap perlakuan. Hal ini diduga selama proses vitellogenesis, hepar mensintesis Vtg dalam jumlah yang banyak sehingga menyebabkan nilai IHS menurun. Selama vitellogenesis terjadi akumulasi protein yolk dan lipid pada oosit. Protein yolk dan lipid adalah material terbesar dalam oosit ikan (Brooks et al., 1997). Selama vitellogenesis sampai waktu pemijahan, glikogen yang terdapat dalam hepar 
menjadi sumber energi untuk memenuhi kebutuhan metabolik selama perkembangan oosit (Hoar et al., 1983; Wiegand, 1996; Reidel et al., 2010). Faktor lingkungan juga memberikan pengaruh terhadap perkembangan gonad ikan. Dalam penelitian ini diukur pula parameter kualitas air yang mendukung bagi kesehatan dan perkembangan ikan. Temperatur air dalam penelitian ini adalah $25-27^{\circ} \mathrm{C}$, suhu tersebut merupakan suhu yang optimum untuk pertumbuhan ikan.

Tabel 2. Data Parameter Kualitas Air

\begin{tabular}{ccc}
\hline No. & Parameter & Kisaran Nilai \\
\hline 1. & Temperatur $\left({ }^{\circ} \mathrm{C}\right)$ & $25-27$ \\
2. & $\mathrm{pH}$ & 7 \\
3. & $\mathrm{DO}(\mathrm{mg} / \mathrm{l})$ & $3,8-7,6$ \\
4. & $\mathrm{COD}(\mathrm{mg} / \mathrm{l})$ & $8-48$ \\
\hline
\end{tabular}

Menurut Hoar et al. (1983), ikan yang hidup di daerah tropis, dapat berkembang biak dengan baik sepanjang tahun di perairan suhu yang tinggi (26$31^{\circ} \mathrm{C}$ ). Cornish dan Smit (1995), menyebutkan bahwa peningkatan temperature air mampu menginduksi vitellogenesis dan pemijahan pada ikan Cyprinidae. Nilai Dissolved Oxygen (DO) pada akuarium pemeliharaan berkisar antara 3,8 - 7,6 mg/l, Chemical Oxygen Demand (COD) yang berkisar antara 8 - 48 mg/l dan nilai pH 7 masih merupakan batas normal bagi pertumbuhan ikan.

\section{KESIMPULAN DAN SARAN}

Berdasarkan hasil dan pembahasan, kesimpulan yang diperoleh sebagai berikut:

1. Perkembangan oosit ikan nilem dapat dipacu dengan pemberian estradiol-17 $\beta$. Pemberian estradiol-17 $\beta$ dosis $126 \mu \mathrm{g} / \mathrm{kg}$ BB meningkatkan proprosi oosit tahap V3-V5, sedangkan dosis 210 $\mu \mathrm{g} / \mathrm{kg}$ BB meningkatkan proporsi oosit tahap V6V7.

2. Perkembangan oosit ikan nilem dapat dipacu dengan pemberian pakan dengan kandungan protein yang berbeda. Pemberian pakan dengan persentase protein $25-30 \%$ mampu memacu perkembangan oosit tahap V3-V5, sedangkan pakan dengan persentase $35-40 \%$ dapat memacu perkembangan oosit tahap V6-V7.

3. Perkembangan oosit ikan nilem dapat dipacu dengan kombinasi pakan dengan kandungan protein dan estradiol-17 $\beta$ dengan dosis berbeda. Pemberian pakan dengan persentase rendah (25$30 \%$ dan penambahan estradiol-17 $\beta$ dosis 126 $\mu \mathrm{g} / \mathrm{kg} \mathrm{BB}$ dapat meningkatkan proporsi oosit tahap V3-V5. Pemberian pakan dengan persentase tinggi (35-40\%) dan penambahan estradiol-17 $\beta$ dosis $210 \mu \mathrm{g} / \mathrm{kg}$ BB dapat meningkatkan proporsi oosit tahap V6-V7.

Berdasarkan hasil penelitian tersebut, untuk meningkatkan perkembangan oosit ikan nilem menuju maturasi yang lebih cepat, dapat dilakukan melalui pemberian pakan dengan persentase tinggi (35-40\%) dan penambahan estradiol-17 $\beta$. Dalam penelitian ini tidak diukur kadar estradiol-17 $\beta$ setiap minggunya. Oleh karena itu, perlu dilakukan pengamatan terhadap kadar estradiol-17 $\beta$ di minggu pertama hingga minggu ke delapan pemeliharaan untuk mengetahui dinamika kadar estradiol-17 $\beta$ pada ikan nilem tersebut. Perlu dilakukan penelitian serupa dengan pemeliharaan di kolam.

\section{UCAPAN TERIMA KASIH}

Penelitian ini didanai oleh Riset Unggulan tahun anggaran 2012 atas nama GE Wijayanti.

\section{DAFT AR REFERENSI}

Abassi Z, Shaikh SA, Abassi J. 2011. Serum cholesterol level during vitellogenesis of teleost fish, Cyprinus carpio. Pakistan J. Zool. 43(4): 739-745.

Abidin MZ, Hashim R, Chien ACS. 2006. Influence of dietary protein levels on growth and edd quality in broodstock female bagrid catfish (Mystus nemurus Cuv. \& Val.). Aquaculture Research.37: 416-418.

Asturiano JF, Sorbera LA, Ramos J, Kime DE, Carrilo M, Zanuy S. 2002. Group-synchronous ovarian development, ovulation and spermiation in the european sea bass (Dicentrarchus labrax L.) could be regulated by shifts in gonadal steroidogenesis. Scientia Marina. 66(3): 273-282.

Babin PJ, Cerda J, Lubzens E. 2007. The Fish Oocyte: From Basic Studies to Biotechnological Applications. Netherlands: Springer.

Batubara UM. 2009. Pembuatan pakan ikan dari protein sel tunggal bakteri fotosintetik anoksigenik dengan memanfaatkan limbah cair tepung tapioka yang diuji pada Ikan Nila (Oreochromis niloticus) [skripsi]. Departemen Biologi FMIPA, Universitas Sumatera Utara-Medan.

Brooks S, Tyler CR, Sumpter JP. 1997. Egg quality in fish: "what makes a good egg?". Reviews in Fish Biology and Fisheries. 7: 387-416.

Cabrita E, Robles V, Herraez P. 2009. Methods in Reproductive Aquaculture. London: CRC Press. Hal: 8-25.

Cornish DA, Smit GL. 1995. The correlation between environmental factors and the reproduction of Oreochromis mossambicus. Water SA. 21 (3): 259-263.

Cornish DA. 1998. Seasonal steroid hormone profile in plasma and gonad of the Tilapia, Oreochromis mossambicus. Water SA. 24(3): 257-264.

Estay F, Colihueque N, Araneda C. 2012. Comparison of oogenesis and sex steroid profiles between twice and once annualy spawning of rainbow trout females (Oncorhynchus mykiss). The Scientific World Journal. 2012: 1-7.

Galas J, Epler P, Stoklosowa S. 1999. Seasonal response of carp (Cyprinus carpio) ovarian cells to stimulation by various hormones as measured by steroid secretion: tissue culture approach. Endocrine Regulation. 33: 125-132.

Gunadi B, Lamanto, Febrianti R. 2010. Pengaruh pemberian pakan tambahan dengan kadar protein yang berbeda terhadap jumlah dan fertilitas telur induk gurame. Prosiding Forum Inovasi Teknologi Akuakultur.

Gunasekera RM, Shim KF, Lam TJ. 1995. Effect of dietary protein level on puberty, oocyte growth and egg chemical composition in the Tilapia, Oreochromis niloticus (L.). Aquaculture. 134: 169183.

Halver JE, Hardy RW. 2002. Fish Nutrition. 3rd ed. San Diego: Academic Press. p 144.

Heidari B, Roozati SA, Yavari L. 2010. Changes in plasma levels of steroid hormones during oocyte development of Caspian kutum (Rutilus frisii kutum, Kamensky, 1901). Animal Reproduction. 7(4): 373-380.

Hoar WS, Randall DJ, Donaldson EM. 1983. Fish Physiology Volume IX Reproduction Part B Behavior and Fertility Control. New York: Academic Press, Inc.

Luquet P, Watanabe T. 1986. Interaction "nutrition-reproduction" in fish. Fish Physiology and Biochemistry. 2(1-4): 121-129.

Manissery JK, Krishnamurthy D, Bangadhara B, Nandeesha MC. 2001. Effect of varied levels of dietary protein on the breeding 
performance of common carp Cyprinus carpio. Asian Fisheries Science. 14: 317-322.

Melamed P, Sherwood N. 2005. Hormons and Their Receptors in Fish Reproduction. Singapore: World Scientific Publishing.

Nagahama Y. 1994. Endocrine regulation of gametogenesis in fish Int. J. Dev. Biol. 38: 217-229.

Nakamura I, Kusakabe M, Young G. 2009. Differential suppressive effects of low physiological doses of estradiol-17 $\beta$ in vivo on levels of mRNAs encoding steroidogenic acute regulatory protein and three steroidogenic enzymes in previtellogenic ovarian follicles of rainbow trout. General and Comparative Endocrinology. 163: 318-323.

Pangkey H. 2011. Peranan Protein untuk budidaya ikan nila Oreochromis niloticus. Warta WIPTEK. 37: 58-65.

Phartyal R, Singh LB, Goswami SV, Sehgal N. 2005. In vitro induction of vitellogenin by estradiol-17 $\beta$ in isolated hepatocytes of catfish, Clarias gariepinus. Journal ofFish Physiology and Biochemistry. 31(2-3): 241-245.

Reidel A, Boscolo WR, Feiden A, Romagosa E. 2010. The effect of diets with different levels of protein and energy on the process of final maturation of the gametes of Rhamdia quelen stocked in cages. Aquaculture. 298: 354-359.

Roberts HE. 2010. Fundamentals of ornamental fish health. USA: Willey-Blackwell Publishing Ltd. Hal 91-92.

Rovara O, Affandi R, Zairin M, Agungpriyono S, Teolihere MR. 2008. Pematangan gonad ikan sidat betina (Anguilla bicolor bicolor) melalui induksi ekstrak hipofisis. Jurnal Ilmu-ilmu Perairan dan Perikanan Indonesia. 15(1): 69-76.

Samsudin R, Suhenda N, Sulhi M. 2010. Evaluasi penggunaan pakan dengan kadar protein berbeda terhadap pertumbuhan benih ikan nilem (Osteochilus hasselti). Prosiding Forum Inovasi Teknologi Akuakultur 2010. Bogor: Balai Riset Perikanan Budidaya Air Tawar.
Singh PB, Singh V, Srivastava S, Pandey S. 2007. Effects of estradiol$17 \mathrm{~b}$ and 17a, 20b-dihydroxy-4-pregnen-3-one on different phospholipids metabolism and histological changes in ovary during reproductive growth in the catfish, Heteropneustes fossilis (Bloch). Journal of Enviromental Biology. 28(4): 771778.

Trushenski JT, Kasper CS, Kohler CC. 2006. challenges and opportunities in finfish nutrition. North American Journal of Aquaculture. 68: 122-140.

Tyler CR, Sumpter JP, Witthames PR. 1990. The dynamics of oocyte growth during vitellogenesis in the rainbow trout (Oncorhynchus mykiss). Biology of Reproduction. 43: 202-209.

Utiah A. 2008. Penampilan reproduksi induk ikan baung (Hemibagrus nemurus Blkr) yang diimplantasi estradiol-17 $\beta$ dan tiroksin. Pacific Journal. 1(3): 277-286.

Wang Y, Lou S. 2007. Influence of exogenous gonadotropin and sexual steroids on ovary development in Japanese eel Anguilla japonica. J. Fish. Soc. Taiwan. 34(3): 261 - 273.

Wiegand M. 1996. Composition, accumulation and utilization of yolk lipid in teleost fish. Reviews in Fish Biology and Fisheries. 6: 259-286

Wijayanti GE, Simanjuntak SBI, Sugiharto. 2005. optimalisas potensi reproduksi ikan nilem (Osteochilus hasselti C.V.) melalui kajian gametogenesis. Seminar Nasional Hasil-hasil Penelitian Perikanan UNDIP; 2005 Nov 30; Semarang, Indonesia.

Yaron Z, Levavi-Sivan B. 2011. Endocrine Regulation of Fish Reproduction. In: Farrell AP, editor. encyclopedia of fish physiology: from genome to environment. Vol. 2. San Diego: Academic Press. p.1500-1508.

Zadmajid V, Imanpoor MR, Shabani A, Baharlouei A. 2012. evaluation of egg production and sex steroid profiles in the goldfish Carassius auratus during four consecutive seasons. Global Veterinaria. 9(3): 367-375 